University of Montana

ScholarWorks at University of Montana

UM Graduate Student Research Conference (GradCon)

Apr 12th, 2:30 PM - 3:50 PM

\title{
College students' reasons for depression nondisclosure in primary care
}

\author{
William Meyer \\ University of Montana - Missoula, william.meyer@umontana.edu \\ Patrick Morrison \\ Pacific University, pdubkmk@pacificu.edu \\ Anayansi Lombardero \\ University of Montana - Missoula, anayansi.lombardero@umontana.edu \\ Kelsey Swingle \\ University of Montana - Missoula, kelsey.swingle@umontana.edu \\ Duncan Campbell \\ University of Montana - Missoula, Duncan.Campbell@mso.umt.edu
}

Follow this and additional works at: https://scholarworks.umt.edu/gsrc

\section{Let us know how access to this document benefits you.}

Meyer, William; Morrison, Patrick; Lombardero, Anayansi; Swingle, Kelsey; and Campbell, Duncan, "College students' reasons for depression nondisclosure in primary care" (2014). UM Graduate Student Research Conference (GradCon). 10.

https://scholarworks.umt.edu/gsrc/2014/posters/10

This Poster Presentation is brought to you for free and open access by ScholarWorks at University of Montana. It has been accepted for inclusion in UM Graduate Student Research Conference (GradCon) by an authorized administrator of ScholarWorks at University of Montana. For more information, please contact scholarworks@mso.umt.edu. 


\title{
College students' reasons for depression nondisclosure in primary care
}

\author{
William J. Meyer, Patrick Morrison, Kelsey Swingle, Graham Payton, Duncan G. Campbell \\ Department of Psychology \\ University of Montana \\ Pacific University
}

Major depressive disorder is a common problem with an estimated lifetime general population prevalence of $16.2 \%$ (Barbui \& Tansella, 2006). Despite the availability of efficacious treatments, depression remains under detected and undertreated in primary care. Shortcomings in treatment likely stem from many factors, including patients' reticence regarding depressive experiences (Bell et al., 2011; Corrigan, 2004; Menke \& Flynn, 2009). The current study expanded existing work (Bell et al., 2011) by examining college students' likelihood of and reasons for depression nondisclosure in primary care. Undergraduates $(n=108)$ read a vignette describing a person with depression and completed measures of disclosure barriers and mental health stigma. Analyses indicated that $26 \%$ of respondents would NOT disclose depression symptoms to their primary care providers, and that an additional $13 \%$ indicated ambivalence about disclosure. Sixty-two percent of women stated they would disclose depressive symptoms, while only $38 \%$ of males stated they would do so $(\chi 2=9.42$, df $4, \mathrm{~N}=92, \mathrm{p}=.051)$. Similar to Bell et al., approximately $51 \%$ of respondents sanctioned medication fears as a disclosure barrier, while roughly $50 \%$ sanctioned uncertainty about how to initiate a depression discussion as a nondisclosure reason. Reports of anger toward the vignette character varied with disclosure willingness $(\mathrm{F}(2,95)=3.82, \mathrm{p}<.05)$, suggesting that nondisclosers feel more stigma than disclosers $(\eta 2=.07)$. Whereas college students' depression care attitudes may have softened in recent years, many remain hesitant to disclose depression. Primary reasons for nondisclosure include medication fears, stigma, and a lack of clarity about initiating the depression conversation. These results reaffirm the importance of well-prepared primary care providers who initiate depression assessment and discussion and who present patients with information about the full range of treatment options, including efficacious alternatives to medication. Because college students may present with depressive symptoms to a variety of healthcare professions, the results of this study are significant to anyone who works in the healthcare field. 